\title{
Práticas letradas de RePRESENTAÇÃO DO OUTRO: ANTÔNIO VIEIRA E O "ÍNDIO ANTES DO INDIANISMO"
}

LITERARY PRACTICES OF REPRESENTATION OF THE OTHER: ANTÔNIO VIEIRA AND THE "INDIGENOUS BEFORE INDIANISM"

\section{Felipe Lima da Silva \\ ORCID 0000-0001-8034-1611}

Universidade do Estado do Rio de Janeiro Rio de Janeiro, RJ, Brasil

\section{Resumo}

Este artigo pretende refletir acerca da configuração da imagem do índio no sermonário de Antônio Vieira, relacionando questôes eminentes do pensamento escolástico e dos interesses da ordem jesuítica. Mais precisamente, será enfocada a visão dos missionários sobre a alteridade do Novo Mundo, ressaltando, por sua vez, a ótica pragmática de Vieira a propósito dos povos recém-descobertos no século XVI.

Palavras-chave: Antônio Vieira, Alteridade, Indígena.

\begin{abstract}
This article intends to reflect about how the image of the indigenous people is represented in Antonio Vieira's sermons, by associating important issues of the scholastic thought with the interests of the Jesuit order. More specifically, the paper will focus on the missionaries' vision about the alterity of the New World, highlighting, in turn, Antonio Vieira's pragmatic point of view regarding the recently discovered nations in the sixteenth century.
\end{abstract}

Keywords: Antonio Vieira, Otherness, Indigenous.

\section{Resumen}

Este artículo pretende reflexionar acerca del trato de la imagen del indio en la parenética de Antônio Vieira, enlazando cuestiones del pensamiento escolástico e de los intereses de los jesuitas. Precisamente, se ocupará de exponer la visión de los misioneros con respecto a la alteridad del Nuevo Mundo, destacando la óptica pragmática de Vieira sobre los pueblos descubiertos en la América en el siglo XVI.

Palabra Clave: Antônio Vieira, Alteridad, Indígena. 
Tomamos de empréstimo, aqui, o título do livro de Alcmeno Bastos, $O$ indio antes do indianismo (2011), para elucidar, através da significação instigante que tal enunciado sugere, a priori, o nosso ponto de vista. Consideramos um tema fulcral, no espectro das questóes coloniais, a posiçáo nada privilegiada da história do nativo da América então portuguesa do século XVII. Da apresentação do livro de Bastos, salientemos as palavras de Roberto Acízelo de Souza (cf. 2011, p. 7) as quais indicam que, diferentemente do caso de nosso romantismo, nas letras coloniais, a questáo do índio ainda não recebeu a atenção devida. Sombra do indianismo, a própria figura do índio, seguimos afirmando, seria um avatar, uma imagem confundida com a própria ideia que dela se formou. Esqueceu-se o índio empírico, ora inimigo do colonizador, ora homem a ser catequisado, e se passou a representar a imagem do ameríndio à imagem do europeu.

Na contramão da ordem do dia dos temas que brindaram a nacionalidade das letras brasileiras, nosso texto caminhará pela via da discussão da figura do índio no cenário das letras coloniais luso-brasileiras dos séculos XVI e XVII. Não buscaremos, neste texto, debater qualquer projeto de historicidade de ordem nacionalista na nossa literatura. A esse respeito, Alcmeno Bastos (2011) apresenta consideraçóes sobre a figura do nativo nas letras do século XVIII que se alinham às passagens magistrais do trabalho magno de Antônio Candido na Formação da Literatura Brasileira (2012).

Para melhor abordar as questões tridentinas que nos propusemos, destaca-se a importância de tratar a produção discursiva da época a partir de condicionamentos históricos apropriados que se alinham no contexto de sua ocorrência. Data de 8 de abril de 1546 a IV sessão do Concílio de Trento que declarou herética a tese sola fide et sola scriptura ("só com a fé e só com a escritura") da Igreja reformada. Nela, Martinho Lutero defendia a dispensa da participaçáo do clero e dos ritos cerimoniais, prescrevendo que o fiel devia colocar-se em contato com a Providência por meio da leitura individual da Bíblia. Em posição diametralmente oposta à tese, o corpo eclesiástico afirmaria a importância dos ritos cerimoniais visíveis, tal como destacaria o poder da Igreja Católica de instruir, santificar e dirigir almas. Em sua análise de tal decreto, Adolfo Hansen reitera o valor proeminente dessa redefinição da Igreja Católica como comunidade de fé, magistério e autoridade, que:

Ampliou a noção de communitas fidelium, a comunidade dos fiéis, determinando-se que necessariamente incluísse todas as populaçóes gentias das terras americanas recentemente invadidas por espanhóis e portugueses, onde as novas ordens religiosas fundadas para combater a heresia, como a Companhia de Jesus, deviam exercer o magistério e o ministério da Igreja (HANSEN, 2005, p. 12). 
Nos séculos XVI e XVII, na Península Ibérica, registram-se em importantes textos de missionários e cronistas relatos acerca de um novo objeto de conhecimento: $o$ indio. Este, por sua vez, foi construído "por meio de um mapeamento descritivo de suas práticas, ao qual se associam prescriçóes teológico-políticas que as interpretam e orientam segundo um sentido providencialista da história" (HANSEN, 1998, p. 351). Paralelamente, Portugal assumiu o decisivo papel de nação eleita por Deus difusora da verdadeira fé no Novo Mundo.

Os habitantes desta margem do Ocidente foram agrupados sob este corpo nominal - o índio -, e constituíram uma figura da alteridade cujo reflexo espelha contrastes marcantes em relação à sociedade ocidental do Velho Mundo. Em linhas gerais, pode-se afirmar que os representantes dessa nova alteridade, sem Estado, seriam classificados como almas selvagens ou animais sem alma, tratados como aptos a serem assimilados pelas pregaçóes evangélicas e se tornarem conhecedores da Palavra, único meio capaz de unificar a variedade e extensão da terra e das gentes nativas, de conduzir a pluralidade à unicidade de um núcleo produtor que é Deus.

No cerne dessa questão, encontram-se por vezes inúmeras contradiçóes no resultado interpretativo gerado a partir das observaçóes dos europeus, que, à luz dos dogmas católicos, e sob a orientação de seu etnocentrismo, operaram uma máquina hermenêutica do Outro. Isso significa dizer que os colonos buscaram, constantemente, produzir numerosas avaliaçóes não apenas descritivas, mas críticas igualmente, acerca do comportamento dos povos ameríndios, com vista a formar uma silhueta para essa nova alteridade, desenvolvendo, para isso, um corte estrutural

Sob a forma histórica de uma crônica sobre a travessia: cada episódio modula a estranheza com um elemento particular da gama cosmológica [...], acrescentando seu efeito próprio à série na qual a diferença é, ao mesmo tempo, o princípio gerador e o objeto em que acreditar (CERTEAU, 1982, p. 198).

Os embates e as opiniōes são muitos e por vezes divergem. De acordo com a documentação existente, constata-se que houve aqueles que alegaram não existir "nada de bárbaro e de selvagem nessa nação, a não ser que cada um chama[sse] de barbárie o que não é seu costume" (MONTAIGNE, 2010, p. 145); assim como houve quem tenha desenhado o índio como "o mau selvagem, o violento, o canibal, sem história, sem memória e sem formas de organizaçáo política” (NOVAES, 1999, p. 10). O fato é que, à medida que tomava consciência de si mesmo, o europeu forjava a consciência do Outro. $\mathrm{E}$, nesse sentido, o pensamento ocidental foi incapaz de admitir o Outro, ao menos que o reduzisse ao Mesmo, mediante uma empresa de assimilação. Essa 
redução significava, sem dúvidas, converter as práticas indígenas aos costumes estabelecidos desde a Criação. A esse respeito, Sheila Moura Hue nos remonta a algumas práticas resultantes do processo de assimilação mencionado, a saber:

O uso da língua tupi em missas, sermões e cantigas, o emprego de intérpretes para a confissão de índios, a utilização de melodias indígenas como veículo de letras católicas ou mesmo a adoçáo do corte de cabelo curumim pelos órfãos portugueses (2006, p. 23).

Plasmado como um ser perdido cuja alma precisa ser recuperada pelo Grêmio católico, a imagem do índio, a priori, é delineada sob dois contornos: por um lado, pelos aspectos que o caracterizam como o "bom selvagem", segundo pode-se constatar nos textos dos primeiros cronistas; e, por outro, como o "animal", "gentio", "selvagem" e "bárbaro", designativos que conferem, ao novo objeto de conhecimento, o aspecto negativo de "não conhece $[\mathrm{r}] \mathrm{a}$ revelaçáo da verdadeira Igreja, nem a justiça da racionalidade hierárquica do Império, nem o governo da monarquia cristâ" (HANSEN, 1998, p. 352).

Esse novo corpo, o "índio", que classifica a pluralidade desses povos do Novo Mundo, terá presença notável na vasta obra do célebre jesuíta seiscentista Antônio Vieira. Acentue-se que será este o eixo estabelecido para entremear os outros fios deste texto, isto é, uma abordagem das letras coloniais através de alguns sermóes fundamentais do referido orador português que nos permitam configurar, sob a ótica neoescolástica que predominou nas letras sacras coloniais, as impressóes sobre esse novo ser cuja silhueta conceitual se pintava. Esse tema, entretanto, apresenta várias entradas profícuas na produção sermonística e missiva do padre Vieira, podendo ser abordado por um ponto de vista "histórico, teológico, jurídico, antropológico, retóricopoético e linguístico" (OLIVEIRA, 2011, p. 32). Nossa investigação, a priori, não se concentrará na exploração de uma única chave de entrada na questão, mas tentará relacionar a visão providencialista de Vieira com essas múltiplas tópicas, desviando-se de anacronismos, ameaça que sempre ronda esse tipo de abordagem. Dessa maneira, buscaremos enquadrar, pois, o jesuíta em seu tempo, examinando as diferentes concepçóes teológico-políticas assentadas na base da configuração da imagem do índio que a inventio vieiriana representa nas práticas letradas mais variadas.

Partamos da pista deixada por Joáo Adolfo Hansen quando lembrou que as discussóes quinhentistas sobre os indígenas não eram antropológicas, mas teológicas, sobretudo, porque "Deus é o fundamento metafísico do direito, da política e da ética que regulam a invasão e a conquista das novas terras" (HANSEN, 1998, p. 348). Era um duplo papel da Igreja ibérica: ajudar na consolidaçáo do dominum ao fixar o povoamento colonial nas 
regióes ultramarinas; fortalecer o imperium, de modo a suscitar a vassalagem dos povos além-mar.

Manuela Carneiro da Cunha igualmente acrescenta um dado crucial: as imagens dos índios então cunhadas nessa época são permeadas por "uma série de duradouros e etnograficamente duvidosos lugares-comuns" (2012, p. 31). Além disso, pode-se apreender no contato com os textos dos primeiros viajantes que a figura do nativo era, para o imaginário português recémancorado nestas terras, um símile dos habitantes do Éden. Sérgio Buarque de Holanda, em Visão do Paraíso, não deixa de enfatizar que "a crença na realidade física e atual do Éden parecia inabalável” (HOLANDA, 2006, p. 226).

Para Pero Vaz de Caminha, a proposta de leitura dos gestos e costumes do Outro são definidos por um olhar marcado pelos topoi da consciência europeia. Segundo o texto: esta "terra em si é de muitos bons ares, assim frios e temperados [...] Águas são muitas; infindas. E em tal maneira graciosa que, querendo-as aproveitar, dar-se-á nela tudo, por bem das águas que tem" (CAMINHA, 1974, p. 82). Em síntese, acima de todas as descrições, é fácil perceber que a maior riqueza, contudo, seria essa gente cuja "índole era bondosa, [além de ser] 'gente boa e de boa simplicidade"' (CAMINHA, 1974, p. 233). A recorrente ótica reducionista de Caminha, que persiste no topos do deslumbramento da natureza, leva Manuela Carneiro da Cunha a concluir que a

Ideia de não domesticação dessa gente que nada domestica - nem plantas nem animais - é, em Caminha, tão poderosa, que o leva a ignorar a agricultura os índios, a náo dar realce às redes e jangadas que menciona, e a presumir, só para ser desmentido no dia seguinte, que eles sequer tenham casas onde se abriguem (2012, p. 31).

Retratado como um "bom selvagem" nas primeiras missivas remetidas de terras americanas, o nativo torna-se a tópica central das discussóes quinhentistas, avivando sobre a civilização do Velho Mundo um espírito de muitas contradiçóes. Era, por sua vez, recorrente o reforço degenerativo realizado sobre a figura do aborígene, debatida pelos grandes representantes da metrópole, que enxergavam nas práticas deles explosivas manifestaçóes de selvageria e abominação. Um autêntico exemplo é o caso de Pero de Magalhães Gândavo, que, em 1570, no Tratado da Terra do Brasil, chega a definir o nativo como um vegetal, uma erva má que afoga as plantas cristãs, na passagem que declara a impossibilidade de numerar e compreender a multidão bárbara que a natureza semeou no Brasil (cf. GÂNDAVO, 2004, p. 134-5).

A propósito do depoimento de Gândavo sobre a inconstância do nativo, é importante frisar que por vezes essa essência de descontrole dos 
costumes ensinados pelos jesuítas será equivocadamente interpretada pelas lentes dos homens da época. Os europeus do século XVI e os importantes missionários pregadores do século XVII desconsideraram o sistema religioso e complexo operado como prática indígena. Timbrados como seres sem Fé, nem Lei, nem Rei, devido à ausência desses grafemas em seus dialetos, o índio gozou de uma reputação demarcada pela desordem de crenças e de práticas religiosas, uma vez que cronistas e pregadores desconsideravam, na lógica da verossimilhança dos saberes em voga no século XVI, o próprio canibalismo como resultado e processo simultâneos da ritualística Tupi.

Para os povos ameríndios, devorar a carne dos seus contrários não era mera prática de alimentaçáo, mas seguia um exigente protocolo em que o matador (o guerreiro que acumularia a vitória sobre o outro) não poderia comer a carne do sacrificado, ao passo que a tribo dividia os membros do morto segundo uma ordem hierárquica específica.

A esse ponto, convém ressaltar que a senha de entrada para a compreensão do projeto literário do romantismo brasileiro pautado na exaltaçáo da figura do índio, muito se deve ao entendimento que passou a ter os escritores sobre essa liturgia que nada tinha de canibal ( $c f$. CUNHA, 2012, p. 37).

Sabe-se que a "pragmática de mundo" - cara inclusive à Companhia de Jesus, considerada uma Ordem religiosa de notável intervenção nos assuntos ligados à sociedade - é a razão a qual do clero professar a doutrina difundida na bula papal Romanus Pontifex (1455), que deliberava poderes plenos à Coroa portuguesa para administrar as terras conquistadas. Nesse jogo de conquistas e derrotas, a escravidão africana será um grande trunfo resultante das estratégias jesuíticas para isentar os índios do cativeiro. A escravidão africana tornou-se naturalmente aceita na medida em que ela facilitava a catequese indígena. "A introdução de africanos facilita a evangelizaçáo, aliviando o cativeiro indígena e contribuindo para reduzir a autonomia que os moradores retiravam de seu controle sobre o trabalho indígena" (ALENCASTRO, 2000, p. 36).

Situemos que, no âmbito das grandes discussóes sobre a tópica do gentio ameríndio, a bula papal, de 1537 , decretou que os ocidentais e meridionais fossem considerados como seres que têm alma, o que desmantelava - no Concílio de Trento, em Valladoid, na Espanha -, portanto, a tese do dominicano Juan Ginés de Sepúlveda, que defendia, em 1550, a servidão natural dos selvagens. A tese apresenta como lastro de sua argumentação o pensamento aristotélico que distinguia que aquele que podia antever, pela inteligência as coisas, deveria ser considerado senhor e mestre por natureza, ao passo que "aquele que com a força do corpo é capaz de executá-las é por natureza escravo.” (ARISTÓTELES, 2004, p. 144). Na oposição desse argumento, citemos o núcleo de autores da Segunda Escolástica os quais afirmavam que o "esforço da conversão é gesto cristão inalienável do contato 
com os novos povos, independentemente de seu grau de polícia, civilização ou racionalidade." (PÉCORA, 1992, p. 424).

A recusa da tese da servidão natural, considerada herética pelo Concílio de Trento, é deliberada ainda pelos juristas católicos, pois não admitia que qualquer sociedade humana, inclusive bárbara, não fosse revestida pela Graça inata, ainda que não conhecesse a revelação de Cristo. Para os pregadores portugueses, agora no contexto luso-brasileiro, até os índios antropófagos eram detentores de alma e, portanto, deviam ser defendidos náo pelo livre direito da liberdade, mas porque representavam um importante instrumento mapeado e catalogado para a realização da cristianização plena na América Portuguesa. Em outras palavras, a latência dos costumes e da fé cristá na alma dos nativos era uma questão de tempo até desaparecer e dar espaço à caridade garantida por meio do batismo e da recondução do índio (nunca antes assimilado) à comunidade cristã dos fiéis. Além disso, de acordo com a bem fundada leitura de Luiz Felipe de Alencastro sobre a escravidão negreira naquela época, podemos estendê-la ao quadrante aborígene: "o nativo era investido do estatuto de cristáo, que o inabilitava para retornar à liberdade natural, antro da idolatria" (2000, p. 162).

$\mathrm{Na}$ clave do pensamento de matriz neotomista, entáo, o processo de redução do gentio ao corpo místico da Igreja vale-se da obrigação evangélica de "pregar a toda criatura". Para Vieira e os outros escolásticos, o esforço da conversão é dever religioso inalienável do conhecimento dos novos povos. $\mathrm{O}$ nativo - detentor das três potências que lhe conferem alma: intelecto, memória e vontade - tem sua presença instituída na lei natural da graça divina. Desta forma, a inclusão do gentio ao corpo místico da Igreja e do Estado torna-se a causa da base da colonização. Enquanto no Brasil as caixas de açúcar se permutam por africanos, os índios são alvos da política dos enclaves baseados no trabalho compulsório, do qual tentam salvá-los os jesuítas, preocupados em moldar essa alteridade entendida por vezes como uma tabula rasa e submetê-la às ordens do reino da Terra e do Céu. A esse propósito, é oportuno realçar as linhas da carta que Antônio Vieira escreve ao novo rei, D. Afonso VI, datada de abril de 1657 , nas quais o missionário denuncia a responsabilidade portuguesa no genocídio dos índios:

Em espaço de quarenta anos se mataram e se destruíram por esta costa e sertôes mais de dois milhóes de índios, e mais de quinhentas povoaçóes, como grandes cidades, e disto nunca se viu castigo. Proximamente, no ano de 1655, se cativaram no rio das Amazonas dois mil índios, entre os quais muitos eram amigos e aliados portugueses, e vassalos de Vossa Majestade, tudo contra a disposição da lei que veio naquele ano a este Estado; e tudo mandado obrar pelos mesmos, que tinham maior obrigação de fazer observar a mesma lei (VIEIRA, 2014, p. 226-27). 
Não se pode deixar passar em silêncio o dado sobre a onipotência de Portugal no que concerne aos assuntos políticos. No "Sermão da Epifania", de 1662, Vieira expóe o valor providencialista da descoberta dos gentios pelos "Argonautas de Portugal":

Este é o fim para que Deus entre todas as Naçóes escolheu a nossa com o ilustre nome de pura na Fé, e amada pela piedade: estas são as Gentes estranhas e remotas, aonde nos prometeu que havíamos de levar seu Santíssimo Nome: este é o Império seu, que por nós quis amplificar e em nós estabelecer; e esta é, foi, e será sempre a maior e melhor glória do valor, do zelo, da Religião e Cristandade Portuguesa (2000, p. 599).

Ressalta-se ainda que, concedido por Inácio de Loiola, em 1534, e aprovado por bula papal em 1540, o trabalho missionário desenvolvido pela Companhia de Jesus estava ajustado aos atuais preceitos do novo mapamúndi, que os encarregava da efetivaçáo da conversão dos habitantes deste lado do Ocidente ao Catolicismo. Nesse contexto, a disposiçáo dos inacianos se afinava à empresa expansionista do império e colonizadora da Coroa de Portugal, que deliberava caber à nação cristã "avançar sobre o mundo gentio e reduzi-lo à cristandade” (PÉCORA, 1992, p. 434).

$\mathrm{O}$ apelo à condição de terra da Promissão, a qual Vieira estabelece para Portugal, endossa, por meio de profecias e declaraçóes de incisivo caráter político, a onipotência da nação lusitana sobre todas as outras já existentes no desenhado mapa do período seiscentista. Afigura-se oportuno reconstituir suas palavras na História do Futuro, nas quais reserva à nação portuguesa o título de Quinto Império, sucedendo os impérios Assírio, Persa, Grego e Romano, respectivamente. Assim, Portugal seria o Império Universal, representado como "princípio e fim" das maravilhas a serem realizadas pelos portugueses no mundo:

A melhor parte dos venturosos futuros que se esperam, e a mais gloriosa deles, será não somente própria da nação portuguesa, senão única e singularmente sua. Portugal será o assunto, Portugal o centro, Portugal o teatro, Portugal o princípio e o fim destas maravilhas, e os instrumentos prodigiosos delas os portugueses (VIEIRA, 2015, p. 73).

Convém ressaltar por linhas gerais que Vieira, juntamente aos outros jesuítas, não considerava o índio, conforme muito se fazia, sob um esquema "biológico", característico de uma visão na qual o selvagem assumia a natureza de: 
Um ser do inferno verde, uma besta mista, heteróclita, em cuja monstruosidade também se pode ler, pelo avesso, o recalcado das fobias do observador, crente em Deus, temente do diabo, perseguidor da heresia, vassalo fiel que, vindo de uma nação de comerciantes fidalgos, náo vê problema em aliar a ética do perfeito cortesão à acumulação (HANSEN, 1998, p. 347).

Outro importante dado a acrescentar à investigação é o de que, além das inúmeras diferenças que a nova alteridade ameríndia exibia ter em relação à europeia, a grande quantidade de línguas dessa terra que "houve quem chamou ao rio das Amazonas de Babel" (VIEIRA, 2001, p. 428), torna-se um lugar-comum entre as dificuldades que encontraram os missionários no processo de evangelização. Esse lugar, onde reina a divisão e a confusão das línguas, é a Babel no interior no Universo ( $c f$. CERTEAU, 1982, p. 202).

No caso do século XVI e XVII, a falta de conhecimento da língua do gentio, por conseguinte, é o grande obstáculo para o sucesso da missão jesuítica com esses incrédulos, pois "se eu não entendo a língua do Gentio, nem o Gentio entende a minha, como hei de converter e trazer a Cristo?" (VIEIRA, 2001, p. 607).

É sob essas lentes que se pode ler o pensamento de Antônio Vieira no "Sermão do Espírito Santo", em que retrata a questão das línguas e do paralelo entre ensinar e aprender:

Pois se a Santo Agostinho, sendo Santo Agostinho, se à Águia dos entendimentos humanos se lhe fez tão dificultoso aprender a língua Grega, que está tão vulgarizada entre os Latinos, e tâo facilitada com Mestres, com Livros, com Artes, com Vocabulários, e com todos os outros instrumentos de aprender; que serão as línguas bárbaras e barbaríssimas de umas gentes onde nunca houve quem soubesse ler, nem escrever? Que será aprender o Nheengaíba, o Juruuna, o Tapajó, o Teremembé, o Mamaiana, que só os nomes parece que fazem horror?

As letras dos Chinas, e dos Japóes, muita dificuldade têm, porque são letras hieroglíficas, como as dos Egípcios; mas, enfim, é aprender língua de gente política e estudar por letra, e por papel. Mas haver de arrostar com uma língua bruta, e de brutos, sem livro, sem mestre, sem guia, e no meio daquela escuridade e dissonância haver de cavar os primeiros alicerces, e descobrir os primeiros rudimentos dela; distinguir o Nome, o Verbo, o Advérbio, a proposição, o número, o caso, o tempo, o modo e modos nunca vistos nem imaginados, como de homens enfim tão diferentes dos outros nas línguas, como nos costumes; não há dúvida que é empresa muito árdua a qualquer entendimento, e muito mais árdua à vontade que náo estiver muito sacrificada, e muito unida com Deus (VIEIRA, 2000, p. 429). 
A "língua geral" ou "nheengatu", nomes do século XVI para o tupi falado no litoral da América portuguesa, apresenta as propriedades categóricas neoescolásticas da "política católica" do expansionismo português ( $c f$. HANSEN, 2006, p. 17). Pragmaticamente, cabia aprender a língua nativa para aperfeiçoar as práticas de conversão, mas também usar a própria língua indígena como um "eficaz instrumento de colonização", que imprimiria uma consciência e os conteúdos necessários para ativar as relaçôes desta com o saber da doutrina e a fé de Deus.

A colonização por meio das próprias práticas do nativo foi por vezes censurada pelos superiores da Companhia de Jesus, a saber, o primeiro bispo do Brasil, Pedro Fernandes Sardinha. O uso de elementos da cultura do Outro a fim de introduzir a própria cultura - movimento que gerou gramáticas e textos escritos em tupi - parecia algo bárbaro, nas palavras de Sheila Moura Hue, ao "civilizado (e logo devorado) bispo, que não acreditava no princípio humanístico da educação dos índios e não gostava de vê-los nus nas igrejas da Bahia" (2006, p. 22). Guardada as devidas proporções, a assimilação do Outro por intermédio dos instrumentos ressemantizados de sua própria cultura produziu uma nova gramática e uma nova semântica que tornaram possível a pragmática do novo sistema colonial sub species religionis, operando uma "'redução' mais significativa (a possibilidade interpretativa) da alteridade cultural para a cultura ocidental” (AGNOLIN, 2007, p. 22).

Assumindo o uso dessas lentes, é possível apreender o movimento das roldanas do engenhoso pensamento vieiriano, que não param de produzir argumentaçóes sobre o topos da língua indígena, incidindo sobre a causa da necessidade de aprender tantas línguas:

Por isso temos por regra e instituto aprender todos a língua ou línguas da terra, onde imos pregar; e esta é a maior dificuldade e o maior trabalho daquela espiritual conquista, e em que as nossas estrelas excedem muito a dos Magos (VIEIRA, 2000, p. 607).

Em paralelo à aprendizagem das línguas, pode ser ler, em linha d'água, o encarecimento da missão jesuítica acerca da catequização dos ameríndios:

E quanta dificuldade e trabalho seja haver de aprender um Europeu, não com mestres e com livros como os Magos, mas sem livro, sem mestre, sem princípio, e sem documento algum, não uma, senão muitas línguas bárbaras, incultas e hórridas: só quem o padece, e Deus por quem se padece o sabe (VIEIRA, 2001, p. 608).

O "isomorfismo entre língua e civilização" apontado por Luiz Felipe Baêta Neves (1997) está na base da constituição da hermenêutica do Outro, 
operada em Vieira sob a ordem dos padróes retóricos e teológico-políticos específicos do imaginário português que tange a expansão da Fé e do Império. À guisa de esclarecimento, retoma-se o "Sermão da Epifania":

[...] as nossas Estrelas [os missionários], depois de deixarem as cadeiras das mais ilustres Universidades da Europa [...], acomodam-se à gente mais sem entendimento e sem discurso de quantas criou, ou abortou a natureza, e a homens de quem se duvidou se eram homens, e foi necessário que os Pontífices definissem que eram racionais, e não burros (VIEIRA, 2000, p. 610).

A máquina hermenêutica ou a engrenagem da constância exegética opera ininterruptamente, tentando interpretar os costumes desse novo outro encontrado às margens do Ocidente. Além disso, é possível constatar uma busca para acentuar a eminência da conversão de modo a impedir as práticas que integram a essência inconstante do selvagem - produto final da interpretação dos europeus quanto aos povos destas terras. Essa essência inconstante é alçada na argumentação do Padre Vieira no "Sermão do Espírito Santo" (de cujo ano não se tem precisão, mas se postula sobre a possível data da pregação em 1657, antes da partida a uma grande Missão ao Rio Amazonas).

No sermão em questáo, Vieira discursa sobre a língua e a qualidade da gente destas terras, afirmando ser essa "a mais bruta, a mais ingrata, a mais inconstante, a mais avessa, a mais trabalhosa de ensinar de quantas há no mundo" (2001, p. 422). Nesse sentido, o índio é posto sob o signo de um grande paradoxo: "os Brasis ainda depois de crer são incrédulos" (VIEIRA, 2001, p. 423).

Reiteremos que as discussóes existentes em torno da natureza deste índio metamorfoseado da imagem do "bom selvagem" para a do "boçal". A modificação do foco e a construção dessa figura tornam-se o ponto máximo do jogo retórico: o que há no sermão é uma reformulação da caracterização do índio à vista de estratégias bem definidas em Vieira.

A configuração do índio, na clave vieiriana, é operada, portanto, à imagem do "boçal", pois tem uma importância retórica para o discurso do inaciano. De um lado, a figura do selvagem inconstante e desmemoriado constrói relevo para a argumentação contra os colonos, condenando a política desses que não cuidam da catequese indígena. No caso, Vieira convoca, no "Sermão da Primeira Dominga da Quaresma" (1653), os cativeiros injustos para corroborar sua argumentação, usando-os como força da causalidade para os males que caem sobre a terra:

Sabeis, Cristãos, sabeis Nobreza e Povo do Maranhão, qual é o jejum que quer Deus de vós esta Quaresma? Que solteis as ataduras da injustiça, e que 
deixeis ir livres os que tendes cativos e oprimidos. Estes são os pecados do Maranhão: estes são os que Deus me manda que vos anuncie (2000, p. 459).

No prosseguimento do referido sermáo, chega a interpelar duramente seu auditório:

Cristãos, Deus me manda desenganar-vos, e eu vos desengano da parte de Deus. Todos estais em pecado mortal; todos viveis e morreis em estado de condenação, e todos ides direitos ao inferno. Já lá estão muitos, e vós também estareis cedo com eles se náo mudardes de vida (VIEIRA, 2001, p. 459).

Esta outra margem do Ocidente, banhada pelo Atlântico, fenda entre o Antigo e o Novo, proporciona à missáo jesuítica uma apologia da indústria e da graça da Companhia de Jesus a respeito da empresa dificultosa de ensinar a doutrina que integraria o índio ao corpo místico do Estado nacional e da Igreja Universal. No campo da inventio vieiriana, o encarecimento da missão jesuítica de integrar o gentio ao Grêmio católico fica mais translúcido quando observado - paralelamente - com a construção de suas argumentaçóes, que recaem sobre a desfiguração da imagem do "bom selvagem" e acentuam as dificuldades que circundam a empresa da redução. A "amorfia da alma selvagem", designação do antropólogo Eduardo Viveiro de Castro (2002, p. 186), que náo cede a receber as formas que assim quer a ortodoxia católica, e a "inconstância constante" dos índios, [torna-se] tornam-se o lugar-comum em que repousa a eloquência contrarreformista de Vieira.

Com vista a demonstrar, concomitantemente, o imenso trabalho despendido na conversão e a necessidade de permanência do jesuíta ao índio "resgatado", Vieira tece uma alegoria refinada e didática, que náo trata mais de esboçar a imagem do ameríndio vinculada a uma essência não violenta e natural, mas opera metaforicamente como figura de um signo da inconstância e da incredulidade que, em linha d'água, só poderia ser reformado pelo esforço de Atlas que desempenha o pregador, jardineiro fiel, como assim o denominou Ana Lúcia de Oliveira (2011, p. 44). Leiamos Vieira:

Os que andastes pelo mundo, e entrastes em casa de prazer de príncipes, veríeis naqueles quadros e naquelas ruas dos jardins dois gêneros de estátuas muito diferentes, umas de mármore, outras de murta. A estátua de mármore custa muito a fazer, pela dureza e resistência da matéria; mas, depois de feita uma vez, não é necessário que lhe ponham mais a mão; sempre conserva e sustenta a mesma figura; a estátua de murta é mais fácil de formar, pela facilidade com que se dobram os ramos, mas é necessário andar sempre reformando e trabalhando nela, para que se conserve. Se deixa o jardineiro de assistir, em quatro dias sai um ramo que lhe atravessa os olhos, sai outro lhe descompóe as orelhas, saem dois que de cincos dedos lhe fazem sete, e o que pouco antes 
era homem já é uma confusão verde de murtas. Eis aqui a diferença que há entre umas naçóes e outras na doutrina da fé (VIEIRA, 2001, p. 63).

A "bulimia ideológica dos índios" (CASTRO, 2002, p. 190) é que lhe confere esse aspecto de selvagem desmemoriado, que não retém o alimento espiritual, mostrando uma saúde de almas malnutridas. Cria-se, por conta disso, uma tarefa incansável de catequese sobre aqueles que não se mantêm conservados ao aprendizado das Leis Divinas. Assim exibe a solução engenhosamente formulada sob um prisma paradoxal:

Há-se de assentir, e insistir sempre com eles, tornando a trabalhar o já trabalhado, e a plantar o já plantado, e a ensinar o já ensinado, náo levantando jamais a mãos da obra, porque sempre está por obrar, ainda depois de obrada (VIEIRA, 2001, p. 425).

O caminho percorrido já nos possibilita tecer algumas consideraçóes finais. Partamos da citação acima para afirmar que Vieira conduz a imagem do índio à luz de concepçóes da Segunda Escolástica, da qual partilhava crença e saberes comuns com outros representantes de sua ordem. Nesse sentido, todo o seu desempenho retórico funciona ajustado a esta finalidade, que contraria qualquer postulação sobre um caráter afrancesado, setecentista e até pré-iluminista que certas leituras anacrônicas amparadas nos olhares trans-históricos tendem a produzir. Além disso, sua defesa em favor dos índios não lhe imprime traços de benevolência ou de libertário, mas tem amparo nos preceitos, metafísica e politicamente, arraigados às Escrituras. A atribuição ou a produção de uma "alma" para o indígena, como ocorre nas práticas jesuíticas, além da relevância teológica, funda-se também na lógica que pressupóe o selvagem como "um próximo", como no mandamento Amar ao próximo.

É sobre esse terreno que caminha Vieira, não compreendendo o indígena como um ser merecedor de proteçấo ou desprezos infundados, mas como peça importante para a expansão dos tabuleiros social e teológico do Seiscentos. Nesse sentido, o jesuíta também foi um hermeneuta do Outro, responsável por imprimir uma imagem daquele que é, na leitura do etnólogo Frédéric Rognon, a quarta figura da alteridade do Ocidente, depois da mulher, do louco e da criança. Tendo em vista seu pensamento providencialista, defendia a potencialidade do gentio para receber a conversão, ainda que fosse através da guerra justa (cf. HANSEN, 1998, p. 349).

Dessa maneira, a guerra justa define-se como um instrumento religioso para submeter, ainda que à força, o gentio à conversão. $\mathrm{O}$ pressuposto da guerra era Deus, e a doutrina reciclava os tópicos medievais de uma nova "Cruzada", para a qual o que importa é a conversão, ainda que sob o signo 
de uma pragmática antropofagicamente catequética, em que a prática mais repugnante do Outro, a antropofagia, torna-se arma contra ele mesmo, ainda que figurativamente:

Para uma fera se converter em homem, há de deixar de ser o que era, e começar a ser o que não era; e tudo isto se faz matando-a e comendo-a; matando-a, deixa de ser o que era, porque morta já não é fera: comendo-a, começa a ser o que não era, porque comida, já é homem. (VIEIRA, 2001, p. 436).

Partindo dessas consideraçóes, os estudos sobre as representaçóes letradas da colônia luso-brasileira evidenciam para nós uma importante via de acesso a mais ajustada compreensão dos avatares indianistas reproduzidos na literatura brasileira a partir do instituído programa indianista pregado pelo romantismo. Em resumo, o novo mundo forneceu matéria rica amplamente debatida pelos europeus que, à sua maneira, a interpretou, produzindo lugares-comuns ora assentados no deslumbramento da terra, ora fundamentados no desprestígio do homem desta mesma terra. Renovado pelo psicologismo romântico e repetidas vezes interpretado pelos escritores oitocentistas, o índio transcendeu os dados históricos muitas vezes para revelar aquilo que se julgava o melhor da própria cultura brasileira, que, neste caso, nunca deixou de ser também uma imagem de uma nacionalidade aos moldes europeus.

\section{Referências}

AGNOLIN, Adone. Jesuitas e selvagens: a negociaçấo da fé no encontro catequéticoritual americano-tupi (sec. XVI-XVII). São Paulo: Humanitas Editorial, 2007.

ALENCASTRO, Luiz Felipe de. O trato dos viventes: a formaçáo do Brasil no Atlântico Sul (Séculos XVI e XVII). São Paulo: Companhia das Letras, 2000.

ARISTÓTELES. Politica. Trad. Therezinha Monteiro Deustch e Baby Abrão. São Paulo: Nova Cultural, 2004.

BASTOS, Alcmeno. $O$ indio antes do indianismo. Rio de Janeiro: 7Letras/FAPERJ, 2011.

CAMINHA, Pero Vaz de. Carta a El-rei D. Manuel. Lisboa: Imprensa Nacional Casa da Moeda, 1974.

CANDIDO, Antonio. Formaçâo da literatura brasileira: momentos decisivos (17501880). Rio de Janeiro: Ouro sobre Azul, 2012. 
CASTRO, Eduardo Viveiros de. "O mármore e a murta: sobre a inconstância da alma selvagem”. In: A inconstância da alma selvagem - e outros ensaios de antropologia. Sáo Paulo: Cosac \& Naify, 2002, p. 181-264.

CERTEAU, Michel de. A escrita da história. Rio de Janeiro: Forense Universitária, 1982.

CUNHA, Manuela Carneiro da. "Imagens de índios do Brasil no século XVI". In: Índios no Brasil. São Paulo: Claro Enigma, 2012, p. 26-53.

GÂNDAVO, Pero de Magalhães. História da provincia de Santa Cruz. Rio de janeiro: Jose Zahar, 2004.

HANSEN, João Adolfo. "A servidão natural do selvagem e a guerra justa contra o bárbaro”. In: NOVAES, Adauto. (Org.) A descoberta do homem e do mundo. São Paulo: Companhia das Letras, 1998, p. 347-373.

HANSEN, João Adolfo. "A escrita da conversão". In: CASTIGAN, L. H. (Org.). Diálogos da conversão: missionários, índios, negros e judeus no contexto iberoamericano do período barroco. Campinas: Ed. Unicamp, 2005, p. 15-43.

HANSEN, João Adolfo. "Anchieta: poesia em tupi e produção da alma”. In: ABDALA JR, B. \& CARA, S. Moderno de nascença: figuraçóes críticas do Brasil. Sáo Paulo: Companhia das Letras, 2006, p. 11-26.

HOLANDA, Sérgio Buarque de. Visão do Paraíso. São Paulo: Companhia das Letras, 2010.

HUE, Sheila Moura. "Introdução". In: Primeiras cartas do Brasil. Tradução, introdução e notas de Sheila Moura Hue. Rio de Janeiro: Jorge Zahar, 2006, p. 11-27.

MONTAIGNE, Michel de. "Sobre os canibais". In: Os ensaios. Trad. Rosa Freire d'Aguiar. São Paulo: Companhia das Letras, 2010, p. 139-157.

NEVES, Luiz Felipe Baêta. Vieira e a imaginação social jesuítica. Rio de Janeiro: Topbooks, 1997.

NOVAES, Adauto. "A outra margem do Ocidente". In: NOVAES, Adauto (Org.). A outra margem do Ocidente. São Paulo: Companhia das Letras, 1999, p. 7-14.

OLIVEIRA, Ana Lúcia M. de. "'Pregando a toda criatura': Antônio Vieira e a semeadura no novo mundo”. In: JOBIM, J. L.; PELOSO, S. (Orgs.). Descobrindo o Brasil: sentidos da literatura e da cultura no Brasil. Rio de Janeiro: EdUERJ, 2011, p. 29-50.

PÉCORA, Alcir. "Vieira, o índio e o corpo místico". In: NOVAES, A. (Org.). In: Tempo e história. São Paulo: Companhia das Letras, 1992, p. 423-461. 
PÉCORA, Alcir. "Vieira e a condução do índio ao corpo místico do império português". In: CASTIGAN, L. H. (Org.). Diálogos da conversão: missionários, índios, negros e judeus no contexto ibero-americano do período barroco. Campinas: Ed. Unicamp, 2005, p. 83-98.

PÉCORA, Alcir. "O bom selvagem e o boçal". In: AZEVEDO, S.M; RIBEIRO, V.C. (Orgs.). Vieira: Vida e Palavra. São Paulo: Ediçōes Loyola, 2008, p. 55-68.

ROGNON, Frédéric. Os primitivos, nossos contemporâneos. Campinas: Papirus, 1991.

ROUANET, Sérgio Paulo. "O mito do bom selvagem". In: NOVAES, A. (Org.). A outra margem do Ocidente. São Paulo: Companhia das Letras, 1999, p. 415-138.

SOUZA, Roberto Acízelo de. "Apresentação". In: BASTOS, Alcmeno. O indio antes do indianismo. Rio de Janeiro: 7Letras/FAPERJ, 2011, p. 7-8.

VIEIRA, Antônio. Sermões. Org. de Alcir Pécora. São Paulo: Hedra, 2000, Vol. 1.

VIEIRA, Antônio. Sermões. Org. de Alcir Pécora. São Paulo: Hedra, 2001, Vol. 2.

VIEIRA, Antônio. Obra completa Padre Antônio Vieira: Cartas da Missão; Cartas da Prisão. São Paulo: Ediçôes Loyola, 2015. Vol. 2, Tomo I.

VIEIRA, Antônio. Obra completa Padre Antônio Vieira: História do Futuro. Sáo Paulo: Ediçōes Loyola, 2015, Vol. 1, Tomo III.

Felipe Lima da Silva. Professor Substituto de Literatura Brasileira na Universidade do Estado do Rio de Janeiro (UERJ). Doutorando em Literatura Brasileira na UERJ. E-mail: felipe.lima2f@gmail.com 